\title{
Authentication Of Transaction Process In E-marketplace Based On Blockchain technology
}

\author{
Adiyanto' $^{1}$,Rizki Febrianto ${ }^{2}$ \\ STMIK Insan Pembangunan ${ }^{1}$, Universitas Budi Luhur ${ }^{2}$ \\ Jl. Raya Serang Km. 10 Pos Bitung, Kota Tangerang, Banten¹, Jl.Patukangan Utara Ciledug \\ Jakarta Selatan ${ }^{2}$ \\ Indonesia \\ e-mail: adiet031170@gmail.com ,rizkifebrianti41@gmail.com
}

To cite this document:

Adiyanto, A., \& Febrianto, R. (2020). Authentication Of Transaction Process In E-marketplace Based On Blockchain technology. Aptisi Transactions On Technopreneurship (ATT), 2(1), 68-74. https://doi.org/https://doi.org/10.34306/att.v2i1.71

\begin{abstract}
The very rapid development of technology is currently causing a revolution digital and the era of technological disruption or known as industry 4.0. with the presence of this 4.0 industry occurred computer growth and record-keeping automation all fields. This allows every human job to be replaced by robots, causing changes in the trading system that was done directly can now be done online or also known as Marketplace. With trade conducted through the internet, the transaction process is carried out on a traditional or directly, is now turning to the digital transaction process through Internet. The transaction process carried out digitally requires accuracy, security, and good trust between seller and buyer. Management Customer Relations or better known as Customer Relationship Management (CRM) is one model that can be used in maintaining the relationship between the customer and the company. Blockchain technology is technology that is able to maintain the transaction process, to maintain management efficiency identity, tracking system implementation, identifying product authenticity, and synchronization recording data to all parties, is expected to increase trust and the relationship between the customer and the seller.
\end{abstract}

Keywords: Marketplace, Customer Relationship Management, Blockchain, Security

\section{Introduction}

The development of technology [1] is very rapid at this time led to the digital revolution and the era of disruption technology or known as industry 4.0. with the presence of industry 4.0 [2] this happened computer growth and record automation in all fields. With technological developments in Industry 4.0 that exist today allows all activities to be carried out through the internet, starting from daily activities, education, to the process buy and sell. One influence of Industry 4.0 is Marketplace, Marketplace itself is online media website-based where activities are conducted business one of which is in the process of transactions between sellers and buyers. [3] [4] E-marketplaces are also able to provide a great opportunity for MSMEs to overcome problems costs and limitations of experts in use information Technology. [5] [6] With 
the existence of Marketplace as well supported by current technological advances allows anyone able to do transactions without face to face, or process transactions online.

Pandawan E-Marketplace is a local startup engaged in the provider of manufacturing services Open Journal System, in the transaction process Pandawan has already implementing payment processes online. However, the low level of internet security [7] is currently becoming a challenge for the Pandawan Marketplace maintain customer confidence in the company, then needed a security technology that is capable maintain transaction processes that are running on the Marketplace Pandawan, so as to create relationships good trust between buyer and seller. From the existing problems, technology is needed which is able to maintain security in the transaction process. cryptographic technology and internet protocols such as blockchain is one technology that can be used in transaction processing protection. Blockchain is a block data that are interconnected so that it looks like a chain [8], Blockchain also has a technological meaning that resembles ledgers that are safely distributed with use a consensus process to resolve a transaction [7]. With the application of blockchain technology on transaction process in the Marketplace, is expected to be able to increase buyer confidence in the process transactions directly through the internet, so you can good relationship management is established between the seller and buyers, and this trust is guaranteed not only by company but also supported by collaboration between cryptography as well as smart code.

\section{Literature Study}

\subsection{Blockchain}

Blockchain was first introduced by Satoshi Nakamoto in 2008 [9]. Blockchain is the basis data that is distributed and does not require central authority or can be said to be a transaction process without the need verification from third parties [10]. Blockchain also has meaning as a decentralized transaction database so able to record events, notes and record activities in a safe, transparent and efficient system [9]. Technology blockchain has the following characteristics [11] [10].

1. Decentralized. This means that every control is not has absolute authority but rather run decentralized.

2. Data transparency and ease in data auditing. Each user / node is connected into a blockchain network has full copy of the (public) blockchain, starting from the genesis block to the current block.

3. Information distribution. To avoid centralized data storage Each user / node save a copy of the blockchain.

4. Decentralized consensus. Every transaction which is recorded into the blockchain is verified by each user / node that is connected in the network Blockchain. This broke the paradigm consumer centralization.

5. Authentication. Blockchain is resistant to damage both intentional and deliberate manipulation intentionally by irresponsible parties.

\subsection{E-Marketplace}

An e-marketplace is an online trading site that is managed by one party, but the product and information are provided by a seller from a third party. [10] [3]. The fundamental difference between conventional or traditional markets and e-Marketplace lies in the concept of transparency. According to the concept put forward by Warran D. Raisch there are 4 (four) stages of the evolution of e-Marketplace development. these stages are [11]:

- Commodity Exchanges

- Value-Added Services

- Knowledge Networks

- Value Trust Networks 


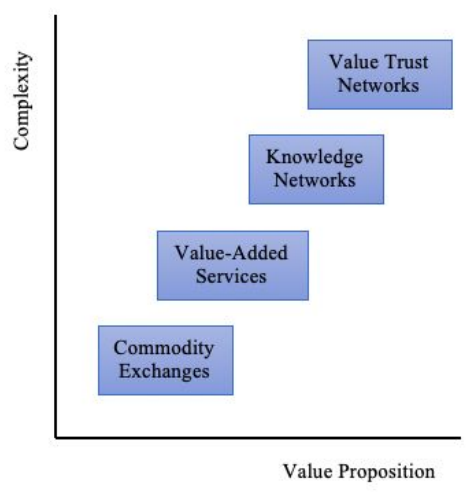

Figure 2. Schema of the E-Marketplace Evolution Stages.

\subsection{Customer Relationship Management}

Customer Relationship Management or also called customer relationship management is an important concept in modern marketing [12]. A broader definition of CRM is a strategy that is broadly applied to help manage relationships or interactions between companies and customers, clients and sales prospects, by utilizing the use of technology to organize and organize, automate, and adjust business processes, specifically in the sales process, including marketing, customer service, technical support, by building a customer interface and feedback management. [13] [14]

\subsection{Transaction Security System}

Transaction security system is an attempt to prevent and detect unauthorized transaction systems. With a transaction security system, data can prevent access by parties who have no rights, and avoid deleting and changing data from parties who have no rights. And able to limit access rights to certain people. [15]

\subsection{Type of Transaction Security System}

There are 2 types of security systems used in the online transaction process, namely: [16]

1. Cryptography System

This system uses a collection of lift or often also called a key. This system functions as an introduction to users and protects all customer transaction information.

2. Firewall System

This system is used to prevent parties who do not have permission / access rights to enter an area that has been protected in a central work unit in the company. Firewall system is not able to prevent the entry of viruses into a system, and this is purely an obstacle from within the organization.

\subsection{Literature Review}

There have been many previous studies on Blockchain and Customer Relationship Management, as well as several previous studies that were used as references in making this journal, including:

1. This research was conducted by Ovi Dyantina, et al (2012) entitled "The Implementation of Web-Based Customer Relationship Management (CRM) (Case Study on Marketing Information Systems at YEN-YEN Stores)". in this study the 
authors present an analysis of the development of web-based CRM in conducting promotions conducted at Yen-Yen Shop. The results of this research journal are a web-based e-CRM system that is able to manage customer data, promote products, product sales data, and manage questions and complaints from customers given to customer service so as to create a good relationship with customers. [17]

2. This study was conducted by S. Freddy (2014) entitled "Performance Measurement Model of Customer Relationship Management in the Banking industry". This study aims to obtain a CRM performance measurement model in the banking industry efficiently and effectively. The results obtained from this study are the CRM Scorecard which is one of the appropriate approach models in measuring CRM performance based on information technology. [18]

3. This research was conducted by Sarah Diffley, Patrick McCole, Elena Carvajal-Trujillo (2018) entitled "Examining social customer relationship management among Irish hotels". This research focuses on overcoming the prolonged effect on hotel performance from the utilization of the CRM process. the results of this study indicate that the CRM process at Irish hotels can improve hotel service innovation, it has a positive impact in the dissemination of information through customers about Irish hotels, so as to maximize the performance of customers, and can improve company finances. The results show that hotel social CRM activities increase hotel service innovation activities. This has a positive impact on the ability to develop customer-connecting capabilities, resulting in a higher level of customer performance. In turn, a higher level of customer performance leads to a higher level of financial performance. [19]

4. This research was conducted by Yudi Setiadi Permana, Asep Id Hadiana, and Eddie Krishna Putra (2019) entitled "Utilization of the Blockchain in the Development of Micro and Small Medium Enterprises Financing Information Systems". The purpose of this research is to build a system that can help MSMEs to find and obtain funding through easy terms and easy bureaucracy. Supported by Blockchain technology in storing transaction data which is expected to increase the security and authenticity of the data can be guaranteed, as well as providing transparency of the financing process to all related parties. [20]

5. This research was conducted by Guntur Dharma Putra, Sujoko Sumaryono, Widyawan (2018) entitled "Design of KSI-Based Identity and Access Management based on KSI and Permissioned Blockchain". It can be concluded that the research is in the form of proposing KSI implementation as well as permissioned blockchain which is used to support the IAZ device IoT device which is implemented on a massive scale. KSI and permissioned blockchain were chosen because their characteristics support scalability. IAM is also designed to provide services with a high level of availability. [21]

6. This research was conducted by Paul Liu (2019) with the title "Method of constructing scalable blockchain by using KanBan to update off-chain transactions states". In his research the author discusses the development of blockchain technology by utilizing KanBan in overcoming the off-chain transaction process. The problem raised from this research is the processing carried out by a limited blockchain so that it requires technology that is able to maximize the process of the blockchain, so in this study discussing KanBan is a system that is able to maximize the blockchain process. [22] 
From the 6 (six) Literature Review described above, many studies have discussed Customer Relationship Management and Blockchain technology. So from previous studies that will be used as a reference by the author in conducting scientific research under the title "Customer Relationship Management in the Authentication of Transaction Processes on the Blockawan E-Marketplace based on Blockchain Technology".

\section{Findings}

\subsection{Problem Analysis}

Pandawan's e-marketplace is a digital startup under the auspices of Alphabet Incubator, Pandawan E-commerce is engaged in providing open journal system services to educational institutions, associations, and organizations that want to become journal publishers. Pandawan itself has collaborated with various associations such as the Indonesian Private Universities Association (APTISI) and the Indonesian Lecturers Association (ADI). in the transaction process, Pandawan has implemented online payment, to maintain security in the transaction process, a technology that is able to maintain the security of transaction data is needed. By maintaining the transaction process, it is expected to be able to maximize customer relationship management in increasing customer trust in the company, so that the relationship between the customer and the company can be maintained properly.

\subsection{Problem solving}

blockchain technology is one technology that can be used to maintain the transaction process. As explained earlier, Blockchain is a ledger that is securely distributed using a consensus process to complete transactions. The use of cryptocurrency or digital currency as a substitute for the original currency based on blockchain technology is able to help customers make transactions directly or peer-to-peer, but still able to maintain customer confidence in the company because in the process of accessing transaction data, cryptographic or smart code is needed. Peer-to-peer transactions themselves mean that ledgers are not centralized or not held by one party, but are decentralized or distributed to all users who make transactions.

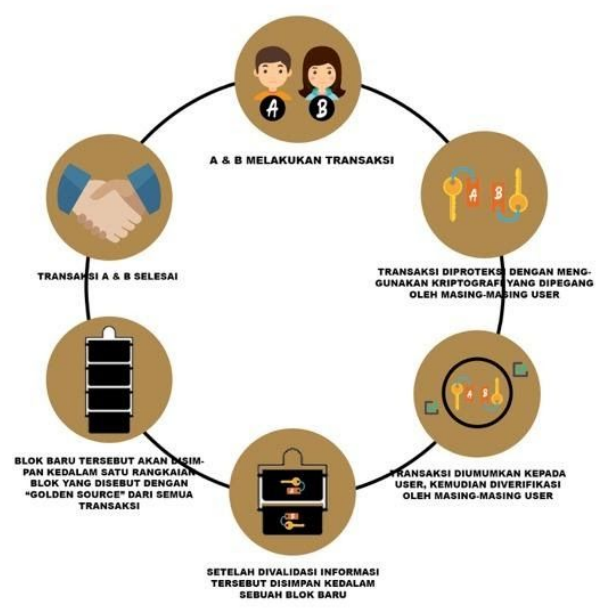

Figure 3. The transaction process on the Blockchain.

Besides this blockchain technology helps companies not to rely on one server or third party, because the recording of the transaction has been distributed to all parties, which are then stored in blocks that can only be accessed by using cryptography. So as to avoid various forms of fraud, such as data manipulation from third parties or data loss due to hacking or server down. This Blockchain technology is guaranteed to be more secure than the current computer system, because all transactions that occur are transparent and decentralized causing data to be able to be checked by users in the network so that reliability can be 
guaranteed. With this blockchain technology, the trust relationship between customers and the Pandawan e-marketplace can be maintained properly, because the transaction data is decentralized and held by each party, both from the seller and the buyer, so transaction data is distributed transparently.

\section{Conclusion}

By applying Blockchain technology to the Pandawan E-Marketplace, 3 (three) conclusions can be drawn as follows:

1. Utilizing blockchain technology on the Pandawan E-Marketplace is able to maintain the security of the ongoing transaction process, because transaction data is distributed to the seller or buyer, which is then stored in a block that can only be accessed via smart code or cryptography.

2. Utilizing blockchain technology on the Pandawan E-Marketplace is able to help companies from cheating committed by third parties, because data is stored by each user.

3. With the blockchain technology, the transaction process can be maintained properly, so that trust and a good relationship between the customer and the company emerge.

\section{References}

[1] Rahardja, U., \& Harahap, E. P. (2019, July). Implementation Of Information Planning and Strategies Industrial Technology 4.0 to Improve Business Intelligence Performance on Official Site APTISI. In Journal of Physics: Conference Series (Vol. 1179, No. 1, p. 012111). IOP Publishing.

[2] Angga, K.P et al. (2017). Rancang Bangun Aplikasi Marketplace penyedia jasa les private di kota Pontianak Berbasis Web. Jurnal Sistem dan Teknologi Informasi,2 (5), pp.1-5.

[2] Apriadi, D., \& Saputra, A. Y. (2017). E-Commerce Berbasis Marketplace Dalam Upaya Mempersingkat Distribusi Penjualan Hasil Pertanian. Jurnal RESTI (Rekayasa Sistem dan Teknologi Informasi), 1(2), 131-136.

[3] Kardianawati, A., Fahmi, S., Haryanto, H., \& Rosyidah, U. (2015). Perancangan Gamifikasi Berbasis Appreciative Inquiry Untuk Peningkatan Daya Saing E-Marketplace UMKM. Techno. Com, 14(3), 173-180.

[4] Dean, T. J., Brown, R. L., \& Bamford, C. E. (1998). Differences in large and small firm responses to environmental context: Strategic implications from a comparative analysis of business formations. Strategic management journal, 19(8), 709-728.

[5] Perdani, M. D. K., Widyawan, W., \& Santosa, P. I. (2018). Blockchain Untuk Keamanan Transaksi Elektronik Perusahaan Financial Technology (Studi Kasus Pada Pt Xyz). Semnasteknomedia Online, 6(1), 1-14.

[6] Bhiantara, I. B. P. (2018, September). Teknologi Blockchain Cryptocurrency Di Era Revolusi Digital. In Seminar Nasional Pendidikan Teknik Informatika (SENAPATI) (Vol. 9, pp. 173-177).

[7] Witami, D. A. D., \& Suartana, I. W. Pengaruh Persepsi Kegunaan, Kemudahan Penggunaan dan Risiko Terhadap Minat Mahasiswa Menggunakan Sistem Blockchain. E-Jurnal Akuntansi, 1346-1376.

[8] Putra, G. D., Sumaryono, S., \& Widyawan, W. (2018). Rancang Bangun Identity and Access Management IoT Berbasis KSI dan Permissioned Blockchain. Jurnal Nasional Teknik Elektro dan Teknologi Informasi, 7(4), 384-390. 
[9] Novo, O. (2018). Blockchain meets IoT: An architecture for scalable access management in IoT. IEEE Internet of Things Journal, 5(2), 1184-1195.

[10] Radkevitch, U., van Heck, E., \& Koppius, O. (2006). Leveraging offshore it outsourcing by SMEs through online marketplaces. Journal of Information Technology Case and Application Research, 8(3), 40-57.

[11] Indrajit, R. E. (2012). Evolusi Marketplace. Jakarta: Acamedia

[12] Tiyani, I. S., \& Irawan, H. (2019). Rancang Bangun Sistem Informasi Electronic Customer Relationship Management (E-crm) Guna Meningkatkan Pelayanan Serta Loyalitas Pelanggan Studi Kasus: Pt Djaya Bersama Putra Prima. IDEALIS: InDonEsiA journaL Information System, 2(4), 118-124.

[13] Hasibuan, A. (2012). Manajemen Perubahan. Jakarta:CV.Andi Offset.

[14] Wahyuni, R., \& Irawan, H. (2018). Penerapan Electronic Customer Relationship Management (E-crm) Dalam Upaya Meningkatkan Loyalitas Dan Pelayanan Terhadap Pelanggan. IDEALIS: InDonEsiA journaL Information System, 1(1), 489-496.

[15] Stiawan, D. (2005). Sistem Keamanan Komputer. Elex Media Komputindo

[16] Dianta, I. A., \& Zusrony, E. (2019). Analisis Pengaruh Sistem Keamanan Informasi Perbankan Pada Nasabah Pengguna Internet Banking. INTENSIF: Jurnal Ilmiah Penelitian dan Penerapan Teknologi Sistem Informasi, 3(1), 1-9.

[17] Dyantina, O., Afrina, M., \& Ibrahim, A. (2012). Penerapan Customer Relationship Management (CRM) Berbasis Web (Studi Kasus Pada Sistem Informasi Pemasaran di Toko YEN-YEN). Jurnal Sistem Informasi, 4(2).

[18] Simbolon, F. (2014). Model Pengukuran Kinerja Customer Relationship Management dalam Industri Perbankan. Binus Business Review, 5(1), 278-287.

[19] Diffley, S., McCole, P., \& Carvajal-Trujillo, E. (2018). Examining social customer relationship management among Irish hotels. International Journal of Contemporary Hospitality Management, 30(2), 1072-1091.

[20] Permana, Y. S., Hadiana, A. I., \& Putra, E. K. (2019). Pemanfaatan Blockchain pada Pembangunan Sistem Informasi Pembiyaan Usaha Mikro Kecil Menengah. Prosiding SISFOTEK, 3(1), 12-17.

[21] Putra, G. D., Sumaryono, S., \& Widyawan, W. (2018). Rancang Bangun Identity and Access Management IoT Berbasis KSI dan Permissioned Blockchain. Jurnal Nasional Teknik Elektro dan Teknologi Informasi, 7(4), 384-390.

[22] Liu, P. (2019). U.S. Patent Application No. 15/719,818. 